\title{
TINJAUAN KHIYAR TERHADAP PERTANGGUNGJAWABAN PENJUAL ONLINE TERHADAP BARANG YANG CACAT
}

\author{
Nikmah Dalimunte \\ Universitas Islam Negeri Sumatera Utara Medan \\ nikmah.dalimunthe75@gmail.com
}

\begin{abstract}
This articles explores the accountability of online sellers on goods defects at their trades. This phenomenon is now growing rapidly. It's so loved by all people mostly. Ease in transcastions and facilitating of buyer to get the desired item from seller is the main selling power. But, from the overall activity, the lack of awareness and understanding of buyers about merchandise selection and checking, often used as an opportunity by seller to give the goods inappropriate trades. Buyer get inappropriate items, either from size, color, brand to defects of goods received. In fiqh, the buying and selling process requires four conditions: Sighat al-'aqd, Mahallul 'aqd, Al'aqidaian and Maudhu'ul 'aqd. That conditions indicate the existence of seller's accountability to the buyer for his merchandise, including online shop. So, the seller must fulfill the terms of trading as a form of responsibility in every transaction, both conventional and online shopping.
\end{abstract}

Keywords: khiyar, liability insurance, online shopping, rejected merchandise

Abstrak: Artikel ini membahas tentang pertanggungjawaban penjual online terhadap barang yang cacat pada dagangannya. Fenomena jual beli online kini memang sedang berkembang pesat. Aktifitas ini begitu digandrungi oleh seluruh lapisan masyarakat. Kemudahan dalam transaksi, apalagi memudahkan pembeli dalam mendapatkan barang yang diinginkan dari penjual menjadi daya jual utama jual beli online. 
Tapi dari keseluruhan aktifitas jual beli online tersebut, kurangnya kesadaran dan pemahaman pembeli dalam memilih barang dagangan serta tidak adanya pemeriksaan fisik dari barang dagangan, seringkali dijadikan kesempatan oleh penjual untuk memberi barang dagangan yang tidak sesuai. Adakalanya pembeli mendapatkan barang yang tidak sesuai, baik dari ukuran, warna, merek hingga kecacatan barang yang diterima. Selama ini, proses jual beli yang diatur dalam figh muamalah secara umum mensyaratkan adanya 4 hal yaitu Sighat al'aqd (ijab qabul), Mahallul 'aqd (obyek perjanjian/barang), Al'aqidaian (para pihak yang melaksanakan isi perjanjian) dan Maudhu'ul 'aqd (tujuan perjanjian). Tentu 4 syarat dalam jual beli tersebut mengindikasikan adanya tanggung jawab penjual kepada pembeli atas barang dagangannya, tak terkecuali jual beli online. Maka, dalam setiap transaksinya, penjual tetap harus memenuhi syarat-syarat jual beli sebagai bentuk pertanggungjawabannya dalam setiap transaksi, baik jual beli konvensional maupun jual beli online.

Kata kunci : khiyar, pertanggungjawaban, penjual online, barang cacat

\section{PENDAHULUAN}

Islam sebagai agama wahyu yang terakhir disampaikan Allah SWT kepada RasulNya yang merupakan sumber, norma, dan nilai normatif yang mengatur seluruh aspek kehidupan dan penghidupan manusia. Maka sehubungan dengan hal tersebut sangat terasa sekali bagaimana perlunya membumikan norma dan nilai tersebut serta sekaligus mengupayakan bagaimana mengintegrasikannya dalam kehidupan umat Islam agar nilai-nilai tersebut selalu dapat muncul kepermukaan. Demikian juga dengan hukum Islam yang bersifat universal harus dapat memberikan jalan keluar terhadap problema-problema yang terjadi dikalangan umat Islam. Hukum Islam merupakan formulasi dari nilai-nilai yang terkandung dalam Al-Quran dan Al-Hadist juga ijma' ulama. Salah satu yang diatur dalam hukum Islam secara muamalah adalah menyangkut hukum jual beli. 
Sebagai sebuah aturan main dalam bermuamalah tentu hukum yang terkait dalam pelaksanaan jual beli harus pula termuat dalam Al-Qur'an dan Sunnah Rasul. Gambaran utama pelaksanaan jual beli pada kedua sumber tersebut wajib dilaksanakan dan dipahami dengan baik oleh umat Islam khususnya dalam bermuamalah. Jual beli tidak hanya sekedar termaktub secara syara' pada kedua sumber hukum Islam. Selain sebagai sarana dalam mencapai kebutuhan hidup, jual beli juga merupakan sarana tolong-menolong antara sesama umat manusia. Di dalam setiap transaksi jual beli, segala jenis prinsip tentu harus dijalankan dengan maksimal agar tidak terjadi pelanggaran syara' pada setiap pelaksanaannya. Misalnya, prinsip transparansi dan kejujuran sangat dijunjung tinggi dalam aktivitas perdagangan. Oleh karenanya, Islam melarang gharar (transaksi dimana salah satu pihak pasti akan mendapatkan keuntungan sedangkan pihak lain mengalami kerugian) dan tadlis (penipuan yang dilakukan penjual karena ketidaktahuan pembeli tentang keadaan pasar secara sempurna) dengan segala bentuknya. Menyembunyikan cacat barang dalam berdagang adalah bentuk pelanggaran terhadap kedua larangan ini, namun dalam aktivitas perdangan di beberapa pasar masih ditemukan indikasi transaksi perdagangan dengan menyembunyikan cacat barang. Allah swt berfirman:

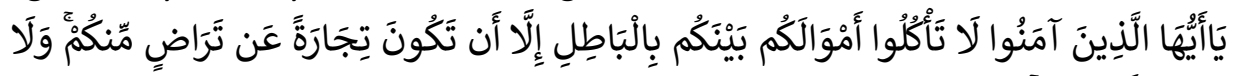

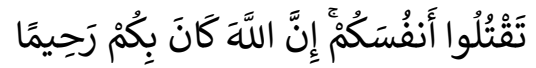

“Hai Orang-orang yang beriman janganlah kamu saling memakan harta sesamamu dengan jalan yang batil, kecuali dengan jalan perniagaan yang berlaku dengan suka sama suka diantara kamu (Q.S. An-Nisa: 29)"

Indikasi ayat tersebut menyebutkan bahwa salah satu aktivitas ekonomi yang saling menguntungkan dan tidak akan merugi serta dapat memenuhi kebutuhan hidup baik dalam mendapatkan barang maupun jasa yaitu jual beli (perniagaan) antara sesama manusia yang harus dilakukan atas dasar 'an taradhi 
minkum yaitu kerelaan atau suka sama suka. Artinya ketegasan ayat tersebut menyatakan bahwa manusia dilarang makan harta sesamanya dengan cara yang batil, kecuali dengan jalan jual beli (perniagaan) yang berlaku secara suka dengan suka.

Dalam pelaksanaannya, segala aktifitas yang terjadi juga harus memegang penuh prinsip keterbukaan dan kejelasan dalam barang yang diperjualbelikan. Penjual harus mengedepankan prinsip tersebut apapun kondisi barang yang dijualnya. la wajib bertanggung jawab dengan segala keadaan barang yang dijual dan menjelaskan kepada si pembeli sebelum terjadi kesepakatan. Meskipun demikian, pertanggungjawaban penjual terhadap penjualan barang cacat menurut hukum Islam sampai saat ini masih terdapat perbedaan dikalangan ulama empat ulama mahzab, seperti Malikiyyah, Syafiiyah, dan Hanafiyah. Adanya perbedaan pendapat para ulama dalam menentukan hukum jual beli dengan syarat bebas dari cacat maka berbeda pula konsekuensi hukum yang diakibatkannya. Bagi Imam Abu Hanifah akan konsekuensinya adalah tidak boleh mengembalikan barang yang telah dibeli, baik diketahui maupun tidak diketahui dan barang yang diperjualbelikan itu umum maupun khusus, sedangkan bagi ulama yang tidak membolehkan jual beli dengan syarat bebas dari semua cacat, seperti pandangan Ibn Hazm, dan Ahmad bin Hanbal, kosekuensinya adalah boleh mengembalikan semua barang yang telah dibeli tersebut.

Upaya-upaya untuk mengantisipasi terjadinya jual beli barang yang cacat, dapat dilakukan oleh penjual dan pembeli khususnya secara online. Penjual harus menerapkan prinsip transparansi kepada pembeli dan menjunjung tinggi kejujuran dan saling tolong menolong. Pembeli juga harus hati-hati dalam membeli barang dengan meneliti sebelum membeli barang tersebut. Nabi saw. bersabda:

البيعان بالخيار ما لم يتفرقا, فإن صدقا وبينا بورك لهما في بيعهما, وإن كذبا وكتما محقت بركة بيعهما. 
"Dua orang yang saling berjual beli punya hak untuk saling memilih selama mereka tidak saling berpisah, maka jika keduanya saling jujur dalam jual beli dan menerangkan keadaan barang-barangnya (dari aib dan cacat), maka akan diberikan berkah jual beli bagi keduanya, dan apabila keduanya saling berdusta dan saling menyembunyikan aibnya maka akan dicabut berkah jual beli dari keduanya" (Diriwayatkan oleh Abu Dawud dan Nasa'i, dan dishahihkan oleh Syaikh Al Bani dalam shahih Jami Hadis No. 2886).

Mengenai pertanggungjawaban penjualan barang-barang cacat oleh penjual, dalam Islam dikenal jual beli Bara'ah (dengan membebaskan si penjual dari cacat barang yang dijual). Maksudnya penjual tidak bertanggung jawab terhadap sesuatu cacat yang terdapat pada barang yang diperjualbelikan dalam setiap keadaan. Namun beberapa ulama fiqh juga mengemukakan beberapa syarat sah jual beli salah satunya adalah jual beli itu terhindar dari cacat, seperti kriteria barang yang diperjualbelikan itu tidak diketahui, baik sejenis, kualitas maupun kuantitas. Gambaran jual beli dalam Islam pada umumnya ialah: jika penjual mensyaratkan bahwa pembeli harus menanggung semua cacat yang ditemuinya pada barang yang dijual secara umum, baik cacat itu diketahui oleh penjual atau tidak, disebutkan atau tidak, dan dilihat atau tidak, maka dalam hal ini para ulama berbeda pendapat dalam menentukan hukumnya, ada yang menyatakan boleh dan ada yang menyatakan tidak boleh.

\section{KONSEP KHIYAR}

Secara etimologi, khiyar artinya: memilih, menyisihkan, dan menyaring. Secara umum artinya adalah menentukan yang terbaik dari dua hal (atau lebih) untuk dijadikan orientasi. Secara terminologis dalam ilmu fiqih khiyar berarti hak yang dimiliki orang yang melakukan perjanjian usaha untuk memilih antara dua hal yang disukainya, meneruskan perjanjian tersebut atau membatalkannya (Abdullah al-Muslih dan Shalah ash-Shawi, Abu Umar Basyir, 2001: 68). 
Hak khiyar ada tiga macam, yaitu: Pertama, Hak pilih di Lokasi Perjanjian (Khiyar Majlis). Khiyar Majlis adalah semacam hak pilih bagi pihak-pihak yang melakukan perjanjian untuk membatalkan perjanjian atau melanjutkannya selama belum beranjak dari lokasi perjanjian. Rasullullah bersabda البيعان بالخيار dua orang yang berjual beli boleh memilih (akan meneruskan jual beli mereka atau tidak) selama keduanya belum bercerai dari tempat akad" (HR. Bukhari dan Muslim).

Kedua, Khiyar Syarat. Khiyar syarat adalah persyaratan yang diminta oleh salah satu dari pihak-pihak yang terkait dalam perjanjian, atau diminta masingmasing pihak untuk dirinya sendiri atau untuk piha lain, untuk diberikan hak menggagalkan perjanjian dalam jangka waktu tertentu. Masa khiyar sebagai syarat paling lama hanya tiga hari tiga malam, terhitung dari waktu akad. Rasullullah bersabda: انت بالخيار في كل سلعة ابتعتها ثلاث ليال "engkau boleh khiyar pada segala barang yang telah engkau beli selama tiga hari tiga malam" (Riwayat baihaqi dan Ibnu Majah).

Ketiga, Khiyar 'aib (cacat). Menurut Al-Juhaili (1989: 261), khiyar 'Aib yaitu sama dengan Keadaan yang membolehkan salah seorang yang akad memiliki hak untuk membatalkan akad atau menjadikannya ketika ditemukan aib (kecacatan) dari salah satu yang dijadikan alat tukar-menukar yang tidak diketahui pemiliknya waktu akad. Yang mengakibatkan terjadinya khiyar disini adalah kerusakan/kekurangan yang mengakibatkan berkurangnya harga dan nilai bagi para pedagang dan para membeli.

Menjalin hubungan kerjasama adalah suatu kebutuhan yang bersifat dharury dalam kehidupan manusia. Asy-Syatibi (1972: 3) menyebutkan bahwa dikatakan dharury karena jalinan kerjasama antar manusia akan terkait dengan mal (harta) yang merupakan kepentingan mutlak dan harus dimiliki oleh setiap manusia dalam memenuhi kebutuhan hidupnya. Hubungan seperti ini merupakan 
suatu cara positif dan telah lama berlaku bagi manusia, sehingga kebutuhan yang satu dengan yang lain sama-sama terpenuhi.

Jual beli merupakan satu bentuk jalinan manusia untuk memenuhi kebutuhannya. Dalam setiap jual beli tentu disyaratkan bahwa setiap barang yang dijual harus memenuhi unsur-unsur yang sesuai dengan hukum Islam. Salah satu syarat yang sering didengar adalah pertanggungjawaban penjual atas setiap barang dagangan.

Islam melihat konsep jual beli itu sebagai suatu alat untuk menjadikan manusia semakin dewasa dalam berpola pikir dan melakukan berbagai aktivitas, termasuk aktivitas ekonomi. Pasar sebagai tempat aktivitas jual beli harus dijadikan sebagai tempat pelatihan yang tepat bagi manusia sebagai khalifah di muka bumi. Maka, sebenarnya jual beli dalam Islam merupakan wadah untuk memproduksi khalifah-khalifah yang tangguh di muka bumi. Abdurrahman bin Auf adalah salah satu contoh sahabat Nabi SAW. Yang lahir sebagai seorang mukmin yang tangguh berkat hasil pendidikan di pasar. Beliau menjadi salah satu orang kaya yang amanah dan juga memiliki kepribadian ihsan.

Pertanyaannya kini adalah, seperti apakah konsep jual beli tersebut yang diperbolehkan dan sesuai dengan pandangan Islam? Untuk menjawab pertanyaan tersebut, maka kita perlu melihat batasan-batasan dalam melakukan aktivitas jual beli. Al-Qomar dan Abdul-Haq (1996) menjelaskan perlu adanya kejelasan dari obyek yang akan dijualbelikan. Kejelasan tersebut paling tidak harus memenuhi empat hal. Pertama, mereka menjelaskan tentang lawfulness. Artinya, barang tersebut dibolehkan oleh Syariah Islam. Barang tersebut harus benar-benar halal dan jauh dari unsur-unsur yang diharamkan oleh Allah. Tidak boleh menjual barang atau jasa yang haram dan merusak. Kedua, masalah existence. Objek dari barang tersebut harus benar-benar nyata dan bukan tipuan. Barang tersebut memang benar-benar bermanfaat dengan wujud yang tetap. Ketiga, delivery. Artinya harus ada kepastian pengiriman dan distribusi yang tepat. Ketepatan waktu menjadi hal yang penting disini. Dan terakhir, adalah precise determination. 
Kualitas dan nilai yang dijual itu harus sesuai dan melekat dengan barang yang akan diperjualbelikan. Tidak diperbolehkan menjual barang yang tidak sesuai dengan apa yang diinformasikan pada saat promosi dan iklan (www.pesantrenvirtual.com/index.php?option=com_content\&task=view\&id=10 62\&itemid=5, Akses 10 Juli 2019).

Jual beli adalah suatu bentuk perjanjian yang telah diberi nama oleh KUHPerdata sehingga dikatakan juga sebagai perjanjian bernama dan diberikan pengaturannya secara khusus. Di dalam KUHPerdata disebutkan bahwa jual beli adalah suatu perjanjian, dengan mana pihak yang satu mengikatkan dirinya untuk menyerahkan suatu barang dan pihak lain untuk membayar harga yang dijanjikan. Secara harfiah, WJS Poerwadarminta (2000: 423) sebagaimana dalam Kamus Umum Bahasa Indonesia menyebut bahwa jual beli terdiri dari dua suku kata yang berlainan arti dan termasuk dalam jenis kata majemuk yang mempunyai arti berlawanan. Namun, menggabungkan dua suku kata tersebut menjadikan satu makna lazim dipergunakan dalam bahasa Indonesia dengan sebutan jual beli, yang artinya: berdagang, berniaga, menjual dan membeli barang-barang. Lalu dikatakan bahwa menjual dengan arti memberikan sesuatu dengan mendapat ganti uang.

Adapun Louis Ma'luf dalam kitabnya (1986: 56) menjelaskan istilah jual beli di dalam kitab-kitab fiqh disebut البيع dengan bentuk jamaknya البيوع. Ditinjau dari

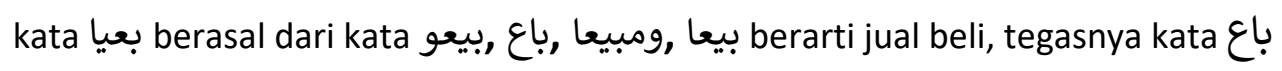

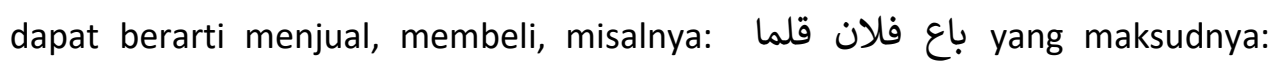
إعطاءالقلم واخذه منه الثمن او بالعكس darinya harga atau sebaliknya). Dengan demikian hal tersebut menunjukkan bahwa kata البيع dapat berarti menjual atau membeli.

Menurut al-Jaziry, (Juz II, 1996: 141) bahwa jual beli adalah مقابلة شئ بالشئ. Yang berarti "tukar menukar sesuatu dengan sesuatu". Sedangkan Ibnu Humam (Juz VI, 1990: 247) memberi arti jual beli dengan (مبادلة المال بالمل) atau diartikan 
juga dengan (تمليك مال بمال) artinya: "pemilikan (memiliki) harta dengan harta". Dalam kitab Subul as Salam, al-Kahlany (Juz III, 1992: 3) memberikan pengertian bahwa jual beli yaitu menurut bahasa artinya kepemilikan harta dengan harta dan ditambahkan menurut syara' harus ada hubungan saling ridha. Dalil hukum jual beli di dalam Al-Quran, diantaranya terdapat pada ayat berikut:

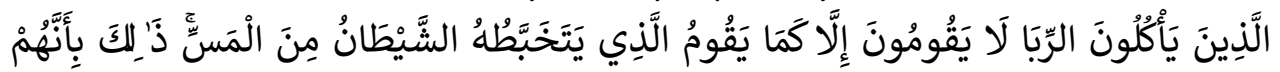

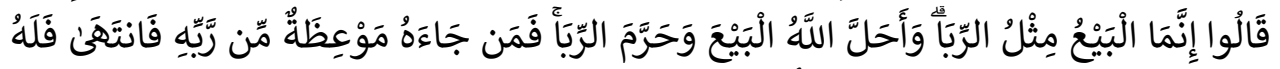

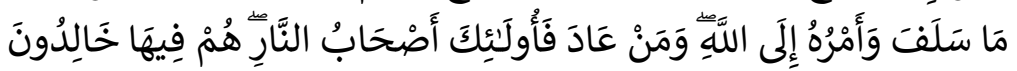

“Orang-orang yang makan (mengambil) riba tidak dapat berdiri melainkan seperti berdirinya orang yang kemasukan syaitan lantaran (tekanan) penyakit gila. Keadaan mereka yang demikian itu, adalah disebabkan mereka Berkata (berpendapat), Sesungguhnya jual beli itu sama dengan riba, padahal Allah Telah menghalalkan jual beli dan mengharamkan riba. Orang-orang yang Telah sampai kepadanya larangan dari Tuhannya, Ialu terus berhenti (dari mengambil riba), maka baginya apa yang Telah diambilnya dahulu (sebelum datang larangan); dan urusannya (terserah) kepada Allah. Orang yang kembali (mengambil riba), Maka orang itu adalah penghuni-penghuni neraka; mereka kekal di dalamnya (Q.S. Al-Baqarah: 275).

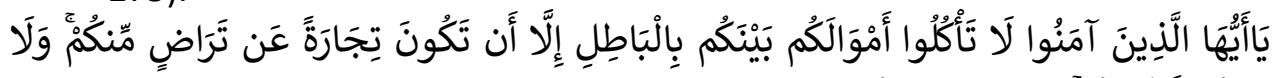

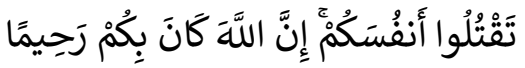

“Hai orang-orang yang beriman, janganlah kamu saling memakan harta sesamamu dengan jalan yang batil, kecuali dengan jalan perniagaan yang Berlaku dengan suka sama-suka di antara kamu. dan janganlah kamu membunuh dirimu. Sesungguhnya Allah adalah Maha Penyayang kepadamu" (Q.S. An-Nisa: 29).

Kedua ayat ini pada dasarnya menjelaskan tentang diperbolehkannya jual beli namun harus mengikuti ketentuan-ketentuan yang mengatur tentang jual 
beli. Selain ayat Al-Quran yang telah dijelaskan, hukum jual beli dalam Hadis Rasulullah saw. Rasulullah ditanya apakah usaha yang paling bagus, Rasulullah ditanya apakah usaha yang paling bagus, Rasulullah menjawab hasil karya tangan seseorang dan jual beli yang mabrur" (HR. al-Hakim). Hal senada juga pada sanad hadis lain (Muhammad Bin Yazid: 737), nabi bersabda, إِنَّمَا الْبَيْعُ عَنْ تَرَاضٍ "sesungguhnya jual beli itu harus suka sama suka" (H.R. Ibn Majah).

Ulama telah sepakat mengatakan bahwa jual beli dan pelaksanaannya tidak dilarang tetapi dibenarkan sejak masa Rasulullah sampai sekarang (Sayyid Sabiq, Juz III, 1977: 75). Dengan demikian kebolehan melakukan jual beli merupakan suatu yang telah pasti. Karena hal ini telah disepakati para ulama, sebagaimana pernyataan Taqiyuddin Abi Bakar yaitu terhadap permasalahan jual beli merupakan ijma' ulama (Juz I, 1998: 239).

Dalam berbagai literatur yang berkaitan dengan kitab jual beli, jumhur ulama sepakat bahwa rukun jual beli mencakup adanya al-'aqidain (pembeli dan penjual), mahallul 'Aqd (barang yang dijual dan harganya), Maudhu' al-'Aqd tujuan akad) serta sighat (kalimat transaksi, ijab dan qabul) (As-Sarbaini, Jilid III, 1978: 4).

Kemudian, jumhur ulama membagi jual beli menjadi dua jenis, yaitu jual beli yang shahih dan jual beli yang batal. Apabila rukun dan syarat jual beli terpenuhi, maka jual beli itu sah/shahih/halal. Sebaliknya apabila rukun dan syarat jual beli itu tidak terpenuhi, maka jual beli itu batal. Oleh karena itu, seseorang yang menggeluti praktek jual beli wajib memperhatikan syarat-syarat sah praktek jual beli agar dapat melaksanakannya sesuai dengan batasan-batasan syari'at dan tidak terjerumus kedala tindakan-tindakan yang diharamkan. Cacat pada akad adalah hal-hal yang merusak terjadinya akad karena tidak terpenuhinya unsur sukarela antara pihak-pihak yang bersangkutan. Hal-hal yang dipandang merusak terjadinya akad adalah paksaan, kekeliruan, penipuan atau pemalsuan dan tipu muslihat. 
Pertama, paksaan. Untuk sahnya suatu akad harus terjadi suka sama suka antara pihak-pihak yang bersangkutan. Para fuqaha membedakan dua macam paksaan yaitu paksaan sempurna (penuh) dan paksaan tidak sempurna. Paksaan dikatakan penuh apabila hal yang dipaksakan melakukan oleh pihak dipaksa dengan adanya ancaman yang menyangkut keselamatan jiwa atau hilangnya sebagian anggota badan, paksaan dikatakan tidak sempurna apabila seseorang suami dipaksa menceraikan istrinya dengan ancaman apabila tidak mau menceraikan akan dibunuh atau akan dipukul yang dikhawatirkan akan mengakibatkan kematian atau cidera pada sebahagian anggota tubuhnya. Apabila paksaan tersebut hanya menyangkut hal-hal selain jiwa dan hilangnya sebagian anggota tubuh badan seperti kalau tidak melakukan hal tersebut tidak akan dinaikkan pangkatnya maka paksaan tersebut tidak sempurna. Kedua, kekeliruan. Kekeliruan yang dimaksud di sini adalah kekeliruan yang terjadi pada objek akad bukan pada subjeknya, kekeliruan pada objek akad mungkin terjadi pada jenisnya atau sifatnya. Kekeliruan dikatakan terjadi pada jenis objek akad apabila misalnya seseorang mengadakan akad jual beli cincin emas, tetapi ternyata cincin itu adalah cincin tembaga. Kekeliruan dikatakan terjadi pada sifat objek akad apabila misalnya seseorang mengadakan akad jual arloji merek dan model tertentu tetapi ternyata arloji yang lain bukan yang diinginkan sesuai kesepakatan (Hasballah Thaib, 2005: 133-135).

Ketiga, penipuan. Penipuan atau pemalsuan yang dimaksudkan disini adalah menyembunyikan cacat pada objek akad agar tampak tidak seperti yang sebenarnya atau perbuatan pihak penjual terhadap barang yang dijual dengan maksud untuk memperoleh harga yang lebih besar. Misalnya orang menjual kambing perahan, beberapa hari sebelumnya tidak diperah agar dikira air susunya amat deras karena susu kambing itu pada saat akan dijual nampak penuh. Keempat, Tipu Muslihat. Tipu muslihat yang terjadi dalam akad misalnya ada seseorang yang sedang menawar harga barang, tetapi oleh si penjual, ada seseorang yang sengaja dibuat menjadi calo untuk menawar lebih dari tawaran 
orang itu sehingga kemudian orang tersebut mau menambah harga dari nominal tawaran sebelumnya (Hasballah Thaib, 2005: 135-137).

Secara umum akad dalam Islam ada tiga macam yaitu akad pertukaran, akad sedekah dan akad investasi. Setiap akad harus memenuhi syarat-syarat dasar tertentu, yaitu akad dinyatakan dengan jelas dan tidak rancu. Akad berlaku setelah suatu penawaran diterima secara tertulis atau lisan. Akad berlaku sendiri dan tidak boleh disepakati di bawah kondisi tekanan dan tidak dalam kegiatan haram (Tarek el-Diwany, Amdiar Amir dan Ugi Suharto, 2003: 177).

Pemerintah sebagai lembaga yang berwenang untuk menjaga stabilitas pasar harus benar-benar mengontrol barang yang beredar dimasyarakat. Ibn Taimiyah (1982: 53), berpendapat mengutip ahli fiqih bahwa pemerintah boleh melenyapkan barang-barang pabrik yang mengandung unsur tipuan, seperti pakaian yang dijahit asal-asalan dan membuang susu yang dicampur air yang dijual oleh seseorang.

Berdasarkan hal tersebut, tugas pemerintah selain mengawasi adalah menghukum pihak yang melanggar aturan yang telah ditetapkan. Misalnya memaksa penjual yang merugikan pembeli untuk memberikan konpensasi atas ganti rugi tersebut.

\section{PRINSIP TRANSPARANSI DALAM JUAL BELI}

Jual beli dalam Islam termasuk dalam kategori bisnis. la merupakan aktivitas yang sangat dianjurkan dalam ajaran Islam. Bahkan, Rasulullah Sendiri pun pernah menyatakan bahwa sembilan dari sepuluh pintu rezeki adalah melalui pintu bisnis. Artinya, melalui jalan inilah pintu-pintu rezeki akan dapat dibuka sehingga karunia Allah terpancar darinya. Berbisnis-dalam bahasa fiqih-adalah sesuatu yang mubah (diperbolehkan), dengan catatan selama dilakukan dengan tidak keluar dari koridor syariat. Dan oleh karenanya semua orang diperkenankan, bahkan dianjurkan untuk melakukan sebatas tidak menabrak rambu-rambu yang telah ditetapkan oleh Allah dan Rasul-Nya. 
Berkaitan dengan masalah bisnis, Al-Quran dan as-Sunnah sangat menekankan arti pentingnya peranan akad (transaksi) bisnis dalam menentukan keabsahan suatu perjanjian bisnis. Setiap akad yang mengandung unsur "riba" sekecil apa pun dalam berbagai macam bentuknya, dalam sebuah transaksi bisnis akan mencederai keabsahannya. Dan oleh karenanya bisa dianggap haram. Sebagai salah satu contohnya adalah transaksi bisnis "utang-piutang" antara kreditur dan debitur. Seorang kreditur, kapan pun diperbolehkan bertransaksi hutang-piutang dengan debitur dengan transaksi yang jujur, transparan dan dapat dipertanggungjawabkan, dengan asas "kerelaan" antarpihak yang bertransaksi. Namun, harus juga diperhitungkan, apakah transaksi itu diniatkan untuk atau berpeluang untuk menzalimi diri, menzalimi pihak lain, atau bahkan salingmenzalimi atau tidak? Jika transaksi itu diniatkan untuk atau berpeluang "menzalimi" semua atau antar pihak yang bertransaksi, maka transaksi itu pun bisa disebut "riba" dan oleh karenanya "diharamkan" (http://suaramuhammadiyah.com/2010/?p=721, akses 15 Juli 2019).

Islam mengenalkan prinsip kejujuran, transparansi, dan etos ta'awun (saling menolong) dalam setiap aktivitas transaksi inilah berbagai bentuk transaksi akan selalu berawal, berproses dan berakhir dengan kerelaan antarpihak, sebab seluruhnya berpotensi untuk "saling-menguntungkan". Dan sebaliknya, Islam melarang segala bentuk "dusta" (kebohongan) dalam segala bentuk transaksi bisnis, yang pada akhirnya - cenderung - akan berawal, berproses dan berakhir dengan ketidak-relaan (kekecewaan) antarpihak yang bertransaksi, sebab secara keseluruhan berpotensi untuk "saling-merugikan". Inilah, yang oleh para mufassir (pakar tafsir) dijelaskan secara panjang lebar ketika mereka menginterprestasikan rangkaian kalimat dalam firman Allah: "Ia tudhlimun wa latudhlamun" (janganlah kamu semua menzalimi dan membiarkan dirimu dizalimi) dalam Q.S. Al-Baqarah ayat 279.

Tiap-tiap syari'at dan peraturan yang diundangkan tidak terlepas dari adanya hikmah dan tujuan, demikian juga halnya dengan hikmah jual beli. Ali 
Ahmad al-Jurjawiy dalam bukunya Hikmat al-Tasyri' Wa Falsafatahu (1962: 135), menyatakan bahwa manusia sebagai makhluk sosial tentu membutuhkan bantuan dan pertolongan orang lain untuk memenuhi kebutuhan dan keperluan hidupnya, baik dengan jalan jual beli, sewa menyewa, upah mengupah, pertanian, perindustrian dan sebagainya. Untuk memenuhi kebutuhan hidupnya tersebut terkadang manusia tidak terlepas dari nafsu yang tidak terkendali, seperti sifat tamak, egois dan serakah sehingga dengan demikian dibuatlah suatu undangundang bagi orang yang bermu'amalah, agar mereka dapat bertindak secara wajar dan tidak sewenang-wenang mengambil harta orang lain yang bukan haknya.

Dengan demikian Allah swt mensyari'atkan jual beli ini sebagai suatu kemudahan dari-Nya untuk hamba-hamba-Nya karena semua manusia secara pribadi mempunyai kebutuhan terhadap barang-barang sandang, pangan dan papan. Kebutuhan seperti ini tidak terputus dan terhenti selama manusia masih hidup atau selama hayat masih dikandung badan karena itu manusia disebut dengan zoon politicon, artinya manusia sebagai makhluk sosial yang senantiasa memerlukan masyarakat lainnya dan dituntut untuk terus berhubungan dengan yang lainnya.

Sebagian besar hubungan itu dapat diketahui melalui pertukaran harta benda, yaitu seseorang memberikan sesuatu yang dimilikinya untuk orang lain, kemudian orang tersebut memberikan pula sesuatu yang dibutuhkan orang tersebut sesuai dengan kebutuhan mereka masing-masing, maka dalam hal ini salah satu yang tercipta adalah jual beli yang merupakan suatu tindakan tolong menolong diantara sesama untuk memenuhi kebutuhan dalam kehidupan seharihari. Hal ini sejalan dengan ungkapan Muhammad bin Isma'il al-Kahlany (1992: 4), bahwa kebutuhan manusia tergantung dengan apa yang ada pada tangan orang lain (temannya), sedangkan temannya itu terkadang tidak mau memberikannya kepada orang lain. Dalam syari'at jual beli itu terdapat sarana untuk sampai kepada maksud (kebutuhan) itu tanpa suatu kesulitan. 
Pada akhirnya dapat diketahui pula bahwa jual beli disyari'atkan untuk terciptanya kehidupan manusia yang teratur dan terhindar dari segala macam perbuatan yang tidak diridhai Allah serta untuk saling menolong dalam tugas dan kebaikan (Q.S. al-Maidah: 2). Allah memerintahkan kepada umat manusia agar saling tolong menolong dalam berbuat kebijakan, dan jual beli termasuk salah satu dari sifat tolong menolong yang diperintahkan oleh Allah untuk memenuhi kebutuhan hidup manusia itu sendiri. Lagipula secara entitas, jual beli tentunya akan menjadi satu kegiatan yang takkan pernah putus dalam aktifitas kehidupan seseorang dimanapun ia berada karena sejatinya aktifitas jual beli merupakan sarana bagi seorang hamba untuk selalu menjalankan syariat Allah dalam hubungan baik dengan sesama manusia (Hablu Min An-Naas).

Berdasarkan maksud dan tujuan jual beli tersebut terkandunglah didalamnya beberapa hikmah:

a. Seseorang dapat memliki benda dengan jalan membelinya.

b. Terpenuhinya hajat dan kebutuhan manusia dengan jalan yang dibolehkan syara', seperti halnya jual beli.

c. Terpeliharanya manusia dalam memiliki harta.

d. Terpeliharanya manusia dari perbuatan yang dilarang dalam pertukaran barang yang dapat merugikan salah satu pihak.

e. Terciptanya tolong menolong untuk memenuhi kebutuhan hidup seharihari dengan jalur tukar menukar.

f. Terjaganya tali silaturrahim sesama manusia.

g. Menjadi salah satu sarana dalam beribadah kepada Allah.

\section{PRINSIP JUAL BELI DENGAN SYARAT BEBAS DARI CACAT}

Dalam literatur hukum Islam dikenal istilah bara'ah yang secara bahasa bermakna terbebas dari aib. Ibnu Rusyd (Juz II, 1990: 138), memberikan penjelasan mengenai istilah ini yaitu bara'ah adalah gambaran bahwa si penjual mensyaratkan kepada si pembeli untuk menangung semua cacat yang ditemukan 
pada barang yang ditemukannya pada barang yang dijual secara umum. Sedangkan menurut Sayyid Sabiq (Juz. III, 1977: 157), bara'ah adalah siapa-siapa yang menjual sesuatu dengan syarat barang tersebut bebas dari segala bentuk cacat yang tidak diketahui maka si penjual tidak bisa dibebaskan dari tanggung jawab.

Apabila mendapati cacat pada barang yang diperjualbelikan, ia berhak memilih karena cacat tersebut baru diketahui setelah berlangsung jual beli, kecuali jika sebelumnya sudah diketahui. Menurut Abdurrahman Al-Jaziri (Juz II, 1990: 196), dia memberikan pengertian sesuai dengan empat ulama mahzab: Menurut Hanafiyya bahwa sahnya bara'ah dari cacat barang yang dijual berlaku pada semua situasi dan kondisi, baik diisyaratkan secara umum atau khusus dengan syarat membebaskan si penjual. Artinya bahwa penjual tidak bertanggungjawab dari setiap cacat barang yang dijual atau dengan syarat membebaskan barang yang artinya terlepas dari cacat. Menurut Malikiyyah mensyaratkan bara'ah dari cacat yang didapati pada barang yang dijual tidak berbeda. Maka, seseorang menjual hewan atau barang dagangan dengan syarat bahwasannya ia dibebaskan dari cacat yang muncul pada barang yang dijual atau dengan syarat ia dibebaskan dari cacat yang bersifat khusus yang seyogyanya bukan tanggung jawab nya jika ternyata kelihatan cacat yang ada pada barang itu, maka seperti ini tidak bermanfaat. Assyafi'iyyah berpendapat bahwa apabila seseorang menjual sesuatu dengan syarat ia bebas dari setiap cacat pada barang yang dijual ketika terjadi akad, maka penjual tidak bisa mensyaratkan seperti itu, baik bara'ah diisyaratkan untuk dirinya sendiri atau diisyaratkan pada barang yang dijual dan bebasnya barang tersebut dari setiap cacat. Dan Hanabila berkata bahwa seseorang apabila menjual barang dagangnya tersebut atau adanya cacat yang bakal timbul sebelum serah terima barang dagangan sedangkan akad telah terlaksana maka persyaratan tersebut menjadi rusak.

Dari penjelasan yang diberikan oleh para ulama mazhab di atas dapat dipahami bahwa jual beli bara'ah adalah adanya syarat dari penjual kepada 
pembeli untuk membebaskan penjual dari segala cacat yang timbul atau mungkin timbul pada barang yang dijual, namun hal ini terlepas dari ulama yang mengkhususkan boleh bara'ah dari cacat.

Para ulama berselisih paham tentang kebolehan jual beli dengan syarat bebas dari cacat. Imam Abu Hanifah membolehkan jual beli dengan syarat bebas dari setiap cacat yang ada baik sepengetahuannya atau tidak, disebutkan atau tidak, dilihat atau tidak (Ibnu Humam, 1990: 396). Imam Ahmad Bin Hanbal sebagaimana yang dikemukan oleh Ibnu Qudamah menjelaskan bahwa orang yang menjual hewan atau yang lainnya dengan syarat bebas dari setiap cacat maka si penjual tidak dapat dianggap bebas baik cacat yang diketahui penjual maupun cacat yang diketahuinya ( Ibnu Qudamah, Juz IV, 1992: 279).

Imam Malik mengatakan dalam Muwatha' (Juz II, 1992: 614), bahwa menurut kesepakatan kami, barang siapa yang menjual seorang hamba laki-laki atau perempuan atau penjual hewan ternak kepada orang lain yang secara lahiriah dalam keadaan tanpa cacat (bebas dari cacat) dan si pembeli pun sudah mau menerimanya, maka apabila dikemudian hari didapati akad cacat dan tidak bisa diminta pertanggungjawaban terhadap barang yang dijualnya itu. Hal ini diperkecualikan apabila dengan sengaja dia menyembunyikan cacat yang memang demikian halnya, maka jual beli dengan syarat bebas dari cacat adalah jelas tidak bermanfaat, sehingga akad jual belinya menjadi batal.

Dengan demikian dapatlah diketahui bahwa beberapa ulama sepakat menyatakan tidak boleh hukumnya jual beli dengan syarat bebas dari cacat, baik diketahuinya oleh si penjual maupun tidak, begitu pula bebasnya diri si penjual dari cacat maupun bebasnya dari barang dagangannya itu sendiri, namun di sisi lain Imam Abu Hanifah membolehkannya. Ibnu Taimiyah menyatakan bahwa pelaku usaha tidak boleh melakukan kecurangan dalam bentuk apapun dalam memasarkan barangnya. Jika terjadi pelanggaran terhadap hal tersebut maka pelaku usaha harus menerima segala konsekuensinya, seperti pemusnahan terhadap barangnya sebagaimana yang pernah dilakukan Umar bin Khattab 
terhadap pelaku usaha yang mencampur susu dengan air. Umar bin Khattab sebagaimana yang dikemukakan Ibnu Taimiyah dalam Al-Hisbah fi Al-Islam membuang susu tersebut. Ibnu Taimiyah juga mengemukakan bahwa boleh melenyapkan barang-barang pabrik yang mengandung unsur tipuan. Seperti pakaian yang dijahit asal-asalan, maka pakaian itu boleh dirobek-robek dan dibakar.

Tentu tidak hanya pada masa sahabat kecurangan ini terjadi. Nabi pernah berangkat bersama para sahabat ke pasar untuk melakukan pengecekan barangbarang dagangan. Kemudian, beliau melewati gundukan makanan, lalu memasukkan tangannya dan mendapati bagian dalam dari gundukan itu basah. Nabi berkata, "Apa ini wahai penjual makanan?" Penjual berkata, "Bagian ini

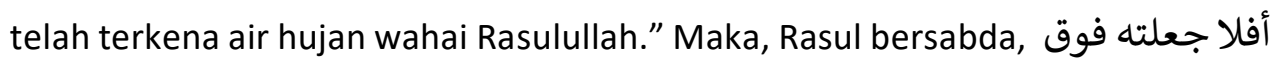
"mengapa engkau tidak meletakkannya di bagian atas, agar orang yang akan membeli dapat melihatnya? Barangsiapa yang berbuat curang kepada kami, maka ia bukan bagian dari golongan kami" (HR Muslim).

Terkait dalam memahami cacat pada barang, kondisi ini harus sejalan dengan pemaknaan yang tersemat pada objek secara hukum Islam, bukan semata-mata dikarenakan adanya ketidaksesuaian pemahaman antar pembeli dan penjual. Adanya hak khiyar dalam Islam bukan berarti hal tersebut ditujukan untuk memberi kesempatan pada satu pihak saja, tetapi keduanya punya hak khiyar yang sama kedudukannya dalam pelaksanaan jual beli. Dalam Kamus Besar Bahasa Indonesia, definisi cacat dalam dilihat sebagaimana berikut (1996: 256):

(a) Kekurangan menyebabkan nilai atau mutunya kurang baik atau kurang sempurna (yang terdapat pada badan, benda, batin, atau akhlak).

(b) Lecet (kerusakan, noda) yang menyebabkan keadaan menjadi kurang baik (kurang sempurna).

(c) Cela atau aib. 
(d) Tidak (kurang) sempurna.

\section{TANGGUNG JAWAB PENJUAL ONLINE ATAS CACAT BARANG}

Pada dasarnya, seorang penjual harus memberi keterangan secara detail terhadap barang dagangannya, baik dari segi kualitas, jenis, ukuran serta beberapa hal yang dianggap penting pada barang dagangan. Persoalan barang dagangan memiliki daya tarik atau tidak berdasarkan keterangan pada barang, itu semua kembali kepada calon pembeli sebagai konsumen yang menentukan keputusan apakah dirinya ingin membeli atau tidak.

Pada transaksi jual beli biasa, segala bentuk barang dagangan dapat dengan mudahnya untuk dilihat oleh pembeli sebelum memutuskan pembelian. ia akan mengecek langsung barang, menimbang, memilih dan menentukan segala apa yang dianggap layak pada barang dagangan untuk dibeli. Hingga akhirnya, setelah proses tersebut dilewati, maka pembeli akan membeli dan membayar sejumlah biaya yang sudah ditentukan penjual atau disepakati bersama (apabila ada proses tawar-menawar harga). Hal ini jauh berbeda dengan transaksi jual beli online, dimana si pembeli tidak tahu sama sekali wajah penjual, bentuk barang secara nyata, hingga tempat atau lokasi penjual menyediakan barang. Sama dengan pembeli, penjual juga tidak mengetahui wajah pembeli, alamat hingga status pembeli tersebut apakah orang dewasa atau tidak. Maka, dalam hal ini, yang harus dilakukan dahulu sebelum terjadi transaksi adalah komunikasi via internet secara e-commerce atau melalui sambungan jaringan komunikasi media sosial seperti whatsapp, mesenger dan sebagainya. Pada proses tanya jawab terkait dagangan online, penulis melihat disini harus sudah ada keterbukaan dari penjual kepada calon pembeli sebagai bagian dari tanggung jawabnya atas barang dagangan. Apalagi hal ini menyangkut tanggung jawab antar penjual dan pembeli.

Jika ditinjau secara mendalam, transaksi jual beli online mempunyai beberapa kesamaan dengan jual beli salam/bai' as-salam sebagaimana yang 
telah dirumuskan ulama fiqh jauh sebelumnya. Baik bai' as-salam maupun transaksi jual beli online sesungguhnya sama-sama merupakan aktivitas jual beli. Jika demikian, tentu dalam jual beli online juga disyaratkan 4 hal sebagaimana pada jual beli pada umumnya yaitu: pembeli, penjual, alat tukar, dan barang yang diperjualbelikan atau obyek transaksi. Kemudian, kesamaan pada transaksi jual beli online maupun bai' as-salam adalah dengan obyek/barang yang ditangguhkan penyerahannya meskipun antara penjual dan pembeli telah menemukan kata sepakat. sejauh ini, pelaksanaan jual beli online maupun bai' as-salam tetap memiliki kesamaan untuk hal tersebut.

Namun, secara spesifik, perbedaan yang paling mencolok antara keduanya adalah dalam hal penawaran, pembayaran, serta pengiriman dan penerimaan. Bahkan, bisa aja terjadi dalam jual beli online kemungkinan untuk penjualan barang yang mengandung unsur judi, penipuan dan riba yang keseluruhannya tersebut dilarang dan diharamkan secara hukum Islam.

Terkait dengan barang dagangan yang diperjualbelikan, penjual online wajib bertanggung jawab mulai dari informasi barang yang dijual hingga barang dagangan tersebut tiba ke tangan pembeli. Pada praktiknya, jual beli online seringkali terjadi dimana antara penjual dan pembeli tidak berada dalam satu kota atau daerah. Mayoritas antara penjual dan pembeli tinggal di propinsi yang berbeda atau satu propinsi berbeda daerah. Maka transaksi ini akan membutuhkan yang disebut kurir atau jasa pengiriman barang hingga sampai ke tangan pembeli. Barang dagangan pun juga akan dibayar dengan beberapa mekanisme yang ditawarkan oleh penjual online. Dikutip dari berbagai sumber, penulis menemukan bahwa dalam transaksi online, pembayaran dilakukan dengan beberapa cara: Pertama, Transaksi model ATM, sebagai transaksi yang hanya melibatkan institusi finansial dan pemegang akun rekening yang akan melakukan pengambilan atau mendeposit uangnya dari akun masing-masing. Kedua, Pembayaran dua pihak melalui perantara kurir, yang dapat dilakukan langsung antara kedua pihak melalui perantara dengan istilah COD (cash on 
delivery). Ketiga, Pembayaran dengan perantaraan pihak ketiga, umumnya merupakan proses pembayaran yang menyangkut debit, kredit ataupun cek masuk. Metode pembayaran yang dapat digunakan antara lain: sistem pembayaran melalui kartu kredit on line serta sistem pembayaran check in line.

Terlepas dengan metode pembayaran tersebut, penulis menganggap bahwa saat terjadi kesepakatan antara penjual dan pembeli hingga terjadinya transaksi pembayaran, maka sesungguhnya telah muncul asas perjanjian dari pembeli kepada penjual dimana perjanjian tersebut sebenarnya lahir sejak awal, yakni melihat informasi barang dagangan hingga membayar sejumlah uang kepada penjual. Tentu transaksi ini juga mengandung norma hukum yang tercantum pada asas-asas perjanjian dalam hukum Islam.

Asas perjanjian dalam hukum Islam yang terkait dengan jual beli online yakni: (1) Asas Ibahah (Mabda' al-ibahah). Dirumuskan dalam adagium "Pada asasnya segala sesuatu itu boleh dilakukan sampai ada dalil yang melarangnya" (2) Asas Kebebasan Berakad (Mabda' Hurriyyah at Ta'aqud). Penjual dalam jual beli online khususnya dapat menuangkan klausul apapun dalam akad asalkan tidak melanggar batasan syariat, yakni makan harta dengan jalan batil atau tidak bertentangan dengan ketertiban umum dan kesusilaan. (3) Asas Konsensualisme (Mabda' ar-Radha'iyyah). Para pihak menyatakan sepakat untuk saling menukar barang dengan uang. Kesepakatan tersebut selanjutnya diaplikasikan melalui tahap ijab dan qabul. (4) Asas Janji itu Mengikat. Dalam jual beli online terdapat slogan yang berbunyi, "Keep No Canceled". Jadi, ketika pembeli sudah memesan barang artinya barang tersebut sudah diikat dan secara tidak langsung sudah ada janji dengan penjual bahwa ia akan membeli barang tersebut. Dalam kaidah ushul disebutkan bahwa, "Perintah itu pada asasnya menunjukkan wajib". (5) Asas Keseimbangan (Mabda' at-Tawazun fi al-Mu'awadhah). Asas keseimbangan dalam jual beli online tercermin pada resiko yang dipikul oleh masing-masing pihak, yakni penjual dan pembeli. Ketika pembeli merasa dirugikan karena barang tidak sesuai dengan spesifikasi yang dipaparkan oleh penjual, maka barang dapat 
ditukar dengan dasar kerelaan penjual. (6) Asas Kemaslahatan. Bahwa perjanjian yang dibuat tidak merugikan salah satu pihak. (7) Asas Amanah. Dalam hukum perjanjian Islam dituntut adanya sikap amanah dari pihak penjual online untuk memberikan informasi sejujurnya kepada pihak pembeli yang tidak banyak mengetahuinya. Hal ini diperlukan untuk menghindari gharar atau kemungkinan resiko yang akan terjadi. (8) Asas Keadilan. Dalam hukum Islam kontemporer dapat diterima suatu asas bahwa demi keadilan, syarat yang tercantum dalam kontrak baku dapat diubah oleh pengadilan apabila memang ada alasan untuk itu (Friska Muthi Wulandari, Jurnal Az-Zarqa', Vol 7, No. 2, Desember 2015: 214-216).

Jika sudah masuk pada asas perjanjian, tentu harus ada tanggung jawab antara keduanya. Khusus kepada penjual, ia wajib mempertahankan keunggulan barangnya mulai dari kualitas, jenis, ukuran, warna dan lain sebagainya, hingga menghindari kondisi barang yang cacat, baik itu sebelum transaksi dilakukan hingga barang sampai ke pembeli. Dengan demikian, pertanggungjawaban penjual sebagai pedagang online tidak menyalahi kaidah-kaidah fiqh dalam urusan jual beli. Dengan menjaga kualitas dan terhindar dari cacat pada barang, tentu akan berefek positif kepada penjual dengan mendapat rating tinggi pada lapak/toko onlinenya dan semakin banyak yang bertransaksi padanya.

Sebagai manusia tidak lepas dari hubungan sosial antara manusia satu dengan yang lainnya, keinginan untuk meningkatkan kemampuan diri, memiliki barang dan berkembang dalam kehidupan akan menghadapkan kita pada interaksi dengan manusia yang lainnya. Berawal dari interaksi tersebut yang pada akhirnya akan menggiring kita untuk menghasilkan sebuah transaksi baik itu jual beli maupun kegiatan dan aktivitas lainnya. Dan dalam proses transaksi inilah dibutuhkan sebuah kejelian dan ketelian untuk menekan dan menghindarkan diri dari tipu daya dan kebohongan. Jadi wajar jika kita sebagai konsumen atau pembeli harus teliti dan jeli sebelum akhirnya memutuskan untuk membeli sesuatu. Sebuah kesadaran bahwa kita membeli barang yang salah akan memicu sebuah kekecewaan akan keputusan kita dalam membeli barang/jasa tersebut. 
Pada dasarnya, jual beli online pada situs-situs yang dianggap terpercaya memungkinkan calon pembeli mendapatkan informasi yang sejelas-jelasnya terhadap setiap barang dagangan yang ada. Adanya istilah testimoni, ulasan dan review dari setiap pembeli pada situs jual beli online dapat menjadi informasi yang berharga pada calon pembeli lain agar tidak salah langkah menentukan barang yang diinginkan. Selain itu, adanya kesempatan untuk bertanya kepada penjual online sejelas-jelasnya terhadap barang dagangannya diharapkan dapat meminimalisir hingga menghapus tindakan jual beli online yang curang dan tidak bertanggung jawab atas barang dagangannya.

\section{SIMPULAN}

Bentuk perlindungan hukum terhadap pembeli atas barang yang cacat sesungguhnya telah diatur dalam Al-Quran, Al-Hadis, dan ljma' Ulama yakni dengan hanya membolehkan bentuk jual beli yang halal dan tidak membenarkan yang riba (diharamkan). Dalam proses jual beli pun harus mengikuti rukun dan syarat jual beli juga dalam pembuatan akad tidak boleh cacat yang dapat merusak akad tersebut yakni akad yang dibuat dengan paksaan, kekeliruan, penipuan atau pemalsuan dan tipu muslihat. Hukum Islam mengenal konsep khiyar, dimana khiyar yang diberlakukan disini adalah khiyar aib. Khiyar aib ini menurut kesepakatan ulama fiqih berlaku sejak diketahuinya cacat pada barang yang diperjualbelikan dan dapat diwarisi oleh ahli waris pemilik hak khiyar. Barang dagangan yang cacat wajib ditanggungjawabi oleh penjual kepada pembeli demi menjaga nilai dan kaidah syariat Islam. Efek positif atas kepercayaan dalam transaksi online akan memberi dampak yang signifikan baik kepada penjual maupun pembeli.

\section{DAFTAR PUSTAKA}

Al-Jaziry, Abdurrahman. 1996. al-Figh al-Mazahib al-Arba'ah, Juz II, Beirut: Dar alFikr. 
Al-Jurjawiy, Ali Ahmad. 1962. Hikmat al-Tasyri' Wa Fasafatah, Juz. II, Mesir: alYusufiyyah.

Al-Kahlany, Muhammad bin Isma'il. 1992. Subul al-Salam, Juz III, Bandung: Maktabah Dahlan.

Al-Muslih, Abdullah dan Shalah ash-Shawi. 2001. Ma La Yasa'ut Tajiru Jahluhu, Penerjemah Abu Umar Basyir, Jakarta: Darul Haq.

Anas, Malik Bin. 1992. Al-Muwatha', Juz II, Istanbul: Darul Al Sahnun.

As-Sarbaini. 1978. Mugni Al Muhtaj, Jilid III, Mesir: Dar Al Fiqr.

Asy-Syatibi. 1972. al-Muwafaqat fi Ushul al-Ahkam, Juz II, Beirut: Dar al-Fikr.

Bakar, Taqiyuddin Abi. 1998. Kifayatul Ahkyar, Juz I, Semarang: Usaha Keluarga.

Departemen Pendidikan dan Kebudayaan. 1996. Kamus Besar Bahasa Indonesia, Jakarta: Balai Pustaka.

El-Diwany, Tarek. 2003. Sistem Bunga dan Permasalahannya, Terj. Amdiar Amir dan Ugi Suharto, Jakarta: Akbar.

http:www.pesantrenvirtual.com/index.php?option=com_content\&task=view\&id $=1062$ \& itemid $=5$

Humam, Ibnu. 1990. Syarh Fath al-Qadir, Juz. VI, Beirut: Dar al-Fikr.

Ma'luf, Louis. 1986. al-Munjid fi al-Lughah, Beirut: Dar al-Masyriq

Poerwadarminta, WJS. 2000. Kamus Umum Bahasa Indonesia, Jakarta: Balai Pustaka.

Qudamah, Ibnu. 1992. Al-Mugniy Wa al-Syarh al Kabir, Juz IV, Lebanon: Darul Fikr. Rusyd, Ibnu. 1990. Bidayah Al-Mujtahid, Juz II, Semarang: Usaha Keluarga.

Sabiq, Sayyid. 1977. Fiqih Al-Sunnah, Juz. III, Beirut: Dar al-Fikr.

Taimiyah, Ibnu. 1982. Al-Hisbah Fil Islam, Madinah: Maktabah 'Alamiyah.

Thaib, Hasballah. 2005. Hukum Kontrak Dalam Fiqih Islam dan Praktek di Bank Sistem Syari'ah, Medan: PascaSarjana Universitas Sumatera Utara.

Wulandari, Friska Muthi. Jual Beli Online yang Aman dan Syar'i (Studi terhadap Pandangan Pelaku Bisnis Online di Kalangan Mahasiswa dan Alumni 
Fakultas Syari'ah dan Hukum UIN Sunan Kalijaga), Jurnal Az-Zarqa', Vol 7, No. 2, Desember 2015.

Yazid, Muhammad Bin. t.t., Sunan Ibnu Majah, Juz II, Beirut: Dar Sahnun. 